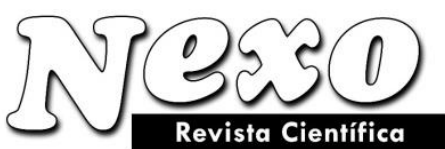

Vol. 36, No. 06, pp. 1777-1784/Diciembre 2021

\title{
The "freight frame" model as a method of freight transport traffic urban organization
}

\section{El modelo del "marco de mercancías" como método de organización urbana del tráfico del transporte de mercancías}

\author{
Valerii A. Haitbaev* ${ }^{*}$ Sergey A. Nikischenkov \\ Samara State Transport University (SSTU),Samara, Russia. \\ *email: haitbaev@samgups.ru
}

(recibido/received: 28-octubre-2021; aceptado/accepted: 07-diciembre-2021)

\begin{abstract}
The paper justifies the use of the "freight frame" as a method of organizing the movement of freight vehicle in large metropolitan areas on the example of Samara city district. The study presents the characteristics of the "freight frame" of major European cities, Kazan and Moscow. A comparative analysis of approaches to the organization of the movement of freight vehicle on the basis of the "freight frame" of Russian cities and cities of foreign countries is carried out. Based on the use of the Yandex.Traffic service, an analysis of the congestion of the main transport highways of the city was carried out, a map of the transport accessibility of the city of Samara was compiled with the calculation of the transport accessibility indices of its districts. To analyze the load of freight transport in the Samara region and the city of Samara, the intensity and composition of the traffic of freight transport on the major streets of the city were calculated using the NETVISION Traffic software and hardware complex, differentiated by months and day time. The result of the analysis allowed to identify the most significant problems of traffic management. On the basis of the used methods of freight traffic analysis, the necessity of implementing the "freight frame" model in the city of Samara was justified. A set of sequential measures is proposed to ensure the step-by-step formation of the freight frame model.
\end{abstract}

Keywords: Freight Frame; Freight Traffic; Modeling; Road Network.

\section{RESUMEN}

El documento justifica el uso del "marco de carga" como método para organizar el movimiento de vehículos de carga en grandes áreas metropolitanas en el ejemplo del distrito de la ciudad de Samara. El estudio presenta las características del "marco de carga" de las principales ciudades europeas, Kazán y Moscú. Se lleva a cabo un análisis comparativo de los enfoques para la organización del movimiento de vehículos de carga sobre la base del "marco de carga" de las ciudades rusas y las ciudades de países extranjeros. Con base en el uso del servicio Yandex.Traffic, se realizó un análisis de la congestión de las principales carreteras de transporte de la ciudad, se compiló un mapa de la accesibilidad al transporte de la ciudad de Samara con el cálculo de los índices de accesibilidad al transporte de sus distritos. Para analizar la carga de transporte de mercancías en la región de Samara y la ciudad de Samara, se calculó la intensidad y composición del tráfico de transporte de mercancías en las principales calles de la ciudad utilizando el software y hardware NETVISION Traffic, diferenciado por meses y días. tiempo. El 
resultado del análisis permitió identificar los problemas más significativos de la gestión del tráfico. Sobre la base de los métodos utilizados de análisis del tráfico de mercancías, se justificó la necesidad de implementar el modelo de "marco de mercancías" en la ciudad de Samara. Se propone un conjunto de medidas secuenciales para asegurar la formación paso a paso del modelo de estructura de carga.

Palabras claves: Freight Frame; Trafico de mercancias; Modelado; Red de carreteras.

\section{INTRODUCTION}

The relevance of the formation of the model of the freight frame is associated with the problem of rational management of the movement of freight transport in large cities. The freight frame has been used all over the world for quite a long time. In many cities with a large amount of transport, experts in the field of traffic management came to the conclusion that the freight frame is necessary to regulate the movement of freight transport and to reduce the negative impact on the environment. Moreover, within the framework of the "smart city" project, the sustainable development of urban agglomerations should be aimed at achieving a high quality of life with positive dynamics of a set of various indicators of a social, environmental and economic nature (Pogorelova y Efimova y Haitbaev, 2019).

The reason for the formation and implementation of the freight frame model should be found, among other things, in the intensive level of urbanization, the transformation of cities into large megacities, the reduction of living spaces for city residents and, accordingly, the reduction in the level of comfort associated with noise and pollution. These external manifestations of urbanization have, among other things, hidden effects on the environment and people causing deterioration of health and a reduction in life expectancy. On the other hand, there is a fairly clear and structured practical task that requires the formation of an appropriate approach, which allows to partially solve the problems of reducing the impact of cargo flows on the environment and people.

Thus, the generalized relevance of the introduction of the freight frame is expressed as: a way to streamline the movement of freight transport in conditions of a high level of urbanization; countering the negative consequences of the negative impact of transport on the environment - harmful emissions, noise, etc.; one of the ways to preserve the roadway; a way to improve road safety; a way to create amenities for city residents; reducing the cost of the transport and logistics component in the price of goods and services.

In order to assess the benefits of the freight frame, we suggest analyzing and evaluating the experience of other countries and cities in Russia when implementing the freight frame model. Based on the analysis carried out using the Yandex.Prob service, cartographic models were obtained that allowed to identify the problems of organizing the movement of freight transport in the Samara city district and to offer a description of the model for the formation of the city's freight frame for their further implementation.

Obviously, the task of selecting or developing a model should be aimed at achieving the set goal, taking into account the required level of costs and results in conditions of insufficient statistical and methodological support for the development and implementation of a freight frame model. Therefore, at present, the task of modeling the freight frame needs not only new theoretical approaches, but also the development of appropriate methodologies, technologies, techniques and algorithms. The purpose of the study is to substantiate the need to introduce a model of the freight frame as a way of organizing road traffic in large cities.

\section{PURPOSE OF THE STUDY}


The movement of freight transport in the city of Samara has long been regulated without sufficient scientific justification and consideration of the impact of freight transport on the environment. As a result, on the roads of Samara, trucks created a huge load - transport and environmental. Since the problem needs to be solved quickly and as efficiently as possible, there is an obvious need to develop a freight frame project. This project is designed not only to delineate the space in which freight transport will move without causing damage to residential areas, but also to encourage carriers to use the transport and logistics infrastructure of the city efficiently. With the introduction of the freight frame, the city becomes more comfortable, safer and more environmentally friendly.

This initiative is reflected in the protocol of a session of the Public Council for the Formation of Environmental Policy of the Samara region. During the meeting, it was proposed to justify the need for a freight frame as a critical infrastructure element of the road network designed to solve the environmental and socio-economic problems of the city. The freight frame will help not only to divide the city streets into 2 zones: the "freight frame" and "residential area" itself, but to maintain the condition of the roadway surface in good condition for a long time. Moreover, this project will increase road safety, reduce traffic jams and reduce traffic accidents.

Thus, the task of substantiating the need to form a model of the freight frame can be formulated as a sequence of measures based on the analysis, evaluation, development and implementation of management decisions on the formation of a methodology and algorithm for modeling the "freight frame" system, which would contribute to achieving the goals of the development of urban agglomerations in the context of improving the comfort of living in cities.

\section{THEORETICAL PART}

Transport is a powerful source of environmental pollution. Of the 35 million tons of harmful emissions, $89 \%$ are from road transport and road construction enterprises. Freight transport is one of the main reasons for the deterioration of the environmental situation in Samara.

Freight transport is also dangerous with a high level of noise, which adversely affects human health. On highways of general significance, the noise level from vehicles can reach 68-78 Db. And on the highways of the district value of $62-78 \mathrm{Db}$, a relatively low noise level is typical for residential streets $-51.2-60 \mathrm{Db}$ (SP 51.13330.2011 Noise protection, 2003).

In an industrial city, there is usually a high percentage of freight traffic on the main streets. An increase in the total traffic flow of freight vehicles, especially large-capacity diesel engines, leads to an increase in the noise level. In general, freight and cars create a heavy noise regime on the territory of cities.

On city highways, trucks make up about $65 \%$ of the total amount of transport. This means that even with a small amount of transport, the noise level will be about $73 \mathrm{Db}$. The noise from the highways of a district status extends not only to the primagistral territory, but also deep into the residential development. It has a detrimental effect on people's health.

In the near future, taking into account the increase in the area of urban areas and the growth of the population of cities, these problems will become threatening to the environment, including the quality of citizens life, and the increase in the costs of organizing freight and passenger traffic, which will undoubtedly affect the cost of goods and services. Moreover, the development of transport systems is characterized not only by an increase in their productivity, technical equipment, and complexity of technological processes, but also by competition in the transportation of goods and passengers (Andronchev y Nikischenkov y Khaitbaev, 2020). The latter involves the use of the same transport routes within the boundaries of urban areas. 
Accordingly, the problem of regulating the movement of freight transport requires a comprehensive and reliable analysis of freight flows, the choice of relevant scientific tools and the justification for the development of a model project of the freight frame.

\section{RESULTS}

The analysis of the experience of the development and implementation of the freight frame in Russia and abroad allowed to determine the main approaches and requirements for its operation. So, for example, for London, this is: the admission to the city only of environmentally friendly trucks. The road signs at the entrance warn about it. If this requirement is violated, a fine of 1000 pounds is charged; a special control scheme was developed for the movement of trucks weighing more than 18 tons, with restrictions from 21.00 to 7.00 from Monday to Saturday, and from 13.00 to 7.00 from Saturday to Monday, entry at the rest of the time with a special pass or paid entry. Special parkings are provided, which are located outside the city or in remote areas of London with the possibility of transshipment of goods; the duty of the London Administration and the Department of Transport of the Mayor's office to conclude contracts only with contractors with a fleet of modern trucks. In Berlin, the following rules of the freight frame are provided: the freight frame in Berlin is presented as an ecological zone; vehicles that meet the standards for exhaust emissions have the right to travel; the environmental zone includes the central part of Berlin within the ring of the S-Bahn city train. A green sticker is put on the car with the need for a permit for the right to use the vehicle. In Berlin, there is no clear scheme of movement of freight transport, although there are restrictions on large loads. The Berlin freight frame is an application of strict standards for emissions and noises and a layered system of transfer point of goods from large-capacity transport to small-capacity. Analysis of the introduction of the freight frame in the Russian Federation. For example, we selected the cities of Kazan and Moscow. The freight frame in Kazan was introduced on July 1, 2013. In the city, from 6:00 to 22:00, a ban on the entry of freight transport is introduced, the movement of cars with a mass of more than 5 tons is prohibited in the period from 6: 00 to 22: 00 on roads bounded by the Kirov Dam, the Lenin Dam, the Millennium Bridge, etc. During the hours of the greatest traffic - from 6:00 to 9:00 and from 16:00 to 21:00 - there is a restriction for vehicles, tractors and mechanisms that carry out the maintenance and repair of city roads. In addition to the existing restrictions, the streets on which large-capacity vehicles can move are defined, which are the cargo frame of the city.

The road network of Moscow is divided into sections. Sections with free movement, weighing more than 2.5 tons (freight frame), and sections where traffic is allowed only for servicing businesses or citizens. In both cases, it is necessary to exit and return to the freight frame from the intersection closest to the destination. The criteria for assigning streets to the freight frame were determined as part of a full-scale study. The model of the freight frame of Moscow is shown on Figure 1 (Official website of the Mayor of Moscow, 2021).

1. A comparative analysis of the formation and use of freight frames of cities showed:

2. For foreign countries: the absence of a rigid route scheme of urban roads, which is a "Freight frame"; developed intelligent traffic management systems; the presence of suburban freight parkings, freight transshipment sites and their fragmentation into small batches; strict requirements for emissions and noise; temporary restrictions on the movement of large-capacity vehicles or the issuance of special passes; a significant system of fines.

3. For cities of the Russian Federation: a clearly defined route scheme of urban roads, which is a "Freight frame"; the absence of freight frames in most cities of Russia; not developed intelligent system of urban transport management (except for Moscow, partly Kazan); traffic on passes or at certain times; lack of parking and transshipment points; complete non-compliance, and sometimes lack of standards for 
emissions and noises making the life of citizens not comfortable; hypertrophied and selective system of fines, especially for emissions and noises.

Within the limits of the conducted study, the analysis and evaluation of the transport and logistics infrastructure of the freight frame formation of the city of Samara was carried out. The current state of the transport and logistics system in large cities and in the region as a whole is considered unsatisfactory both by representatives of the executive authorities and also by the residents of large cities. The analysis of traffic congestion in the city of Samara is shown in Figure 2 and 3 (Yandex.Traffic, 2021).

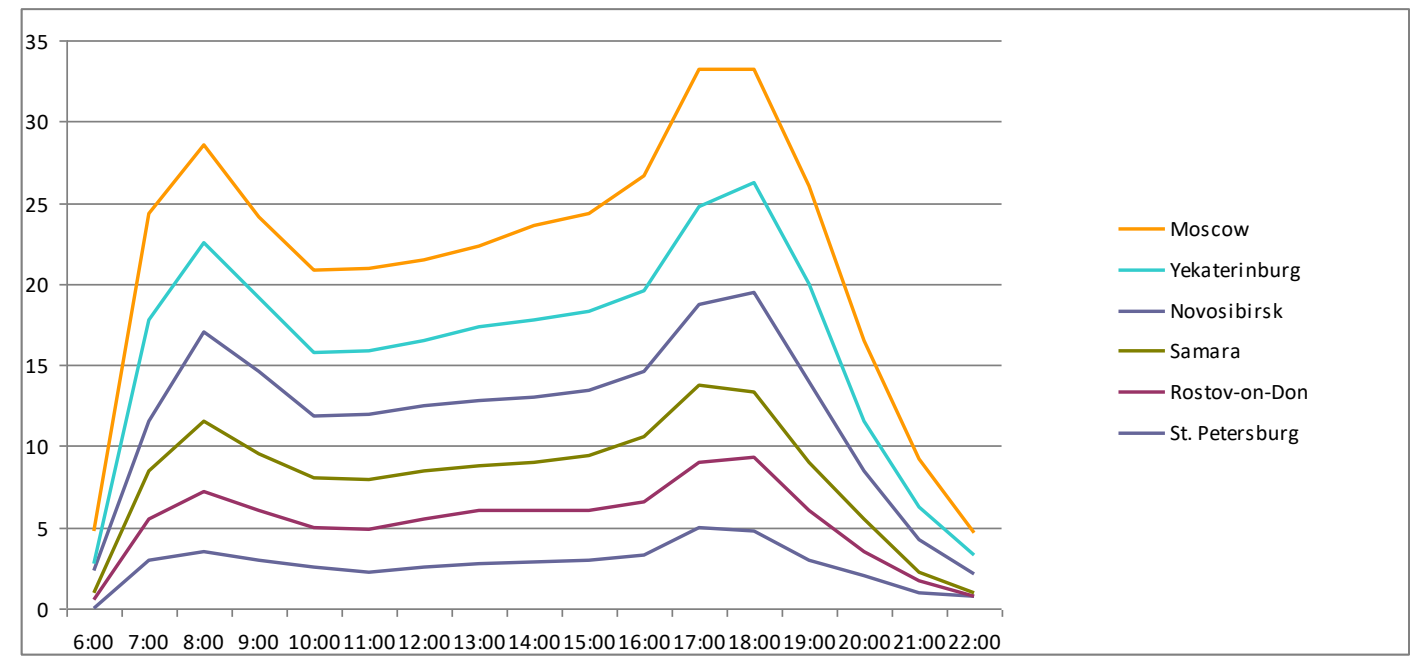

Figure 2. Comparative analysis of traffic congestion in Russian cities

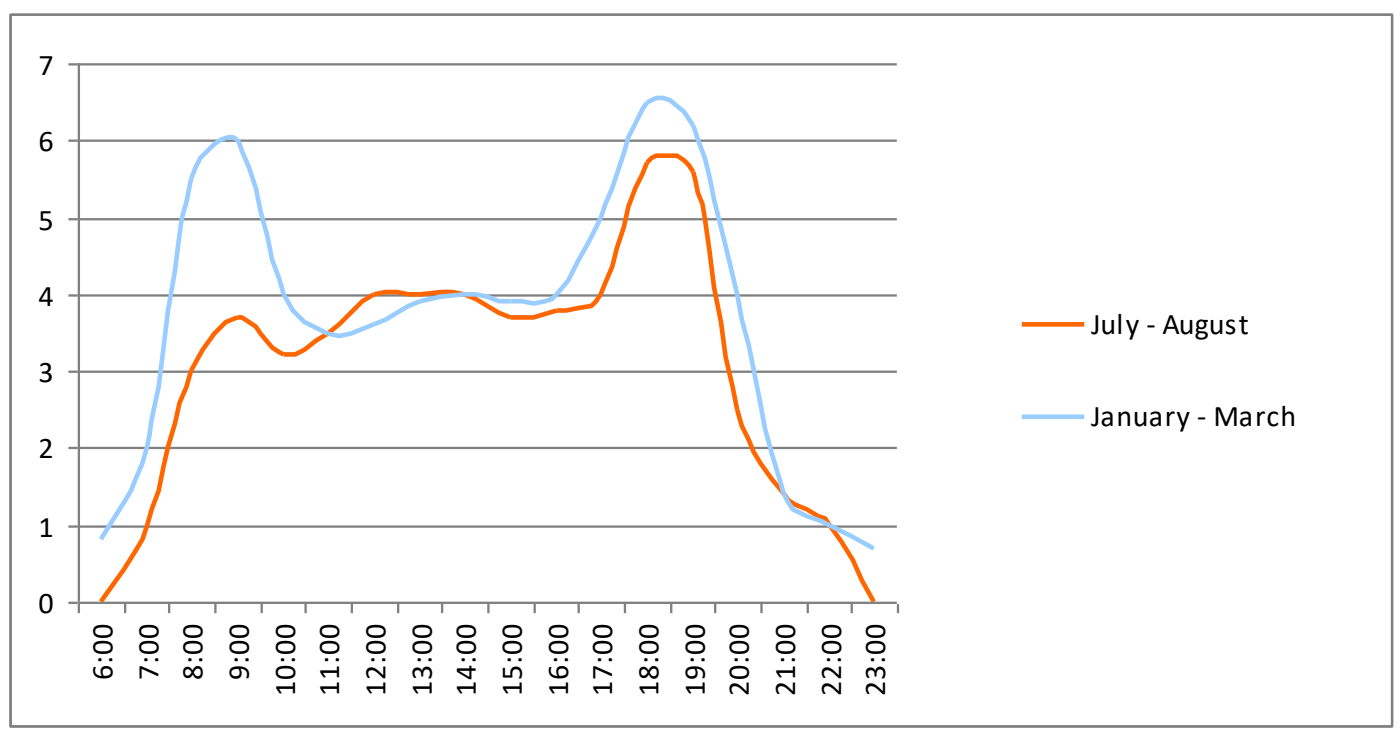

Figure 3. Analysis of traffic congestion in the city of Samara

The graphs show that Samara is on the fourth place among the largest cities in Russia in terms of traffic congestion. In addition, the average score of traffic jams has maximum values in the morning and evening hours, while in the winter time of the year these indicators are higher. 
The indicators of transport accessibility of all districts of the city were also analyzed, the result is presented in Table 1, (Yandex.Traffic, 2021). Obviously, Lenin, Samara, Railway and October districts were the busiest.

Table 1. Transport accessibility index of Samara districts

\begin{tabular}{lc}
\hline \multicolumn{1}{c}{ District } & Transport Accessibility Index \\
\hline Lenin district & 1 \\
Samara district & 1.1 \\
Railway district & 2.3 \\
October district & 2.5 \\
Kuibyshev district (Sukhaya Samarka, Zasamarskaya Slobodka) & 3.7 \\
\hline
\end{tabular}

For 8 months of 2020, as a result of the work of NETVISION Traffic, it was established that 27.1 million cars entered the territory of the Samara region, of which 23.8 million - cars, 2.9 million - trucks, and 280 thousand - passengers cars. 26.9 million various vehicles left, including 24.2 million cars, 2.6 million trucks, and 103,000 passengers cars. The transit flow is 9.3 million vehicles, which confirms the need for transport unloading of the city.

Currently, two main roads of major importance pass through Samara - this is the Moscow Highway and Novo-Sadovaya Street, which are connecting and carry the main transport load, both for the movement of freight transport and for passenger transport. In addition, the development of transport is limited by natural water barriers. Another problem is the insufficient length of allocated tram tracks and the lack of allocated lanes for public passenger vehicles. At the moment, in the city of Samara, there are about 1190 road signs regulating the movement of freight transport. However, their location does not form an integrated system for the movement of freight transport (Yandex.Traffic, 2021). As an example, the diagram for the Samara, Lenin and October districts shows selected road sections with road signs that regulate the traffic of freight transport and are essentially fragments of a freight frame.

Due to the large number of industrial enterprises, it is necessary to transport large volumes of goods for industrial and technical purposes and consumer goods to the territory of Samara, to introduce a freight frame and to divide the city into 2 parts: for the movement of freight transport and a residential area. In our opinion, the justification of the need and the development of a model of the freight frame should include a sequence of the following mandatory measures:

Analysis and evaluation of the city development plan for compliance with the urban planning standard in order to pre-select the city's transport highways for planning the freight frame.

Regionalization of the city with the allocation of the following zones: industrial; residential; administrative; recreational; mixed. Analysis of the road network: analysis and evaluation of the parameters of freight and passenger traffic (intensity, time, volume); calculation of the zones of attraction of freight traffics; determination of the places of generation, distribution, absorption of freight traffics, as well as their trajectories. Formation of a layered system of transport and logistics centers, places of transshipment and temporary storage of goods for the unbundling of large freight shipments and the possibility of using low-capacity vehicles with the right to move along highways intended for passengers adjacent to the transport interchange hub. In the suggested model, the storage locations are the nodes of the graph, which in the first iteration gives the basic contour of the formed model of the "freight frame". Analysis of the project of urban and suburban transport interchange hubs. 
Development of a model of the cargo frame of the city, taking into account the locations of the TIH and Transport Logistic Center, excluding the joint use of transport highways for passenger and freight transportation, as well as the "contact" of transport interchange hubs with highways of the freight frame.

The use of intelligent systems for managing and controlling the functioning of the freight frame, which corresponds to the current state policy of the Russian Federation and links the innovative development of the country with digital transformation in the process of creating, distributing and using information and communication technologies (Kurnikova, et al. 2019).

Formation of a specialized layer of the transport infrastructure graph in the environment of the geographic information system "Municipal geo-portal of Samara" with the necessary information on: the intensity of traffic flows divided by modes of transport; traffic restrictions for individual modes of transport; construction of cartograms of traffic congestion of the road network and its elements.

\section{CONCLUSION}

The most significant results of the study are a reasonable suggestion on the formation of a freight frame that is an infrastructure element of the transport and logistics system of the city and the development of a complex of interrelated measures for the development of a freight frame project. From the point of view of the infrastructural, socio-economic and environmental conditions of the development of urban agglomerations, the task of creating an adequate model of the freight frame is quite reasonable. The level of significant uncertainty of the listed conditions associated with the low efficiency of urban management in Samara significantly complicates the process of developing and implementing the freight frame, which leads to an increase in the budget for the development and implementation of the project, increased impact of negative factors on the environment, loss of planned time for the implementation of the project and other negative consequences. Moreover, the restrictions associated with the violation of the urban planning code further aggravate the prospects for the socio-economic development of the city.

The analysis of the points of view of the residents and the city administration on the problems hindering the development of the city of Samara confirms that there is no misunderstanding about the ways to solve the existing problems. The problem of road traffic congestion and the associated negative environmental factors can be partially resolved by the implementation of the freight frame project, which should find its legislative solution in terms of the integrated development of the city's transport infrastructure with an approved funding procedure. The analysis of the intensity and congestion of the city's transport highways with the determination of the transport accessibility index, the zones with the greatest length and time of road traffic congestion, as well as places of fragmentary regulation of the movement of freight vehicles allows to propose a prototype of the freight frame model in the first iteration after the city regionalization procedure. Further implementation of the suggested measures in the section "Research results", in our opinion, is a fairly reasonable way to develop a freight frame project.

It is obvious that many processes of optimizing transport traffics within the boundaries of urban agglomerations, taking into account technical, economic and environmental requirements, should provide a higher level of quality of citizens life and increase the economic efficiency of urban management. In this context, the freight frame is a fairly effective way to achieve these tasks, which is confirmed by the practice of managing the movement of freight transport in the largest cities of the world.

\section{REFERENCES}

Pogorelova, E.V., Efimova, T.B., Haitbaev, V.A. (2019). Modernization of managing a "smart city" on the basis of digital platforms of knowledge neural management. In: Mantulenko, V. (ed.) International 
Conference "Eurasia: Sustainable Development, Security, Cooperation", SHS Web of Conferences, vol. 71, 04017. EDP Science, Les Ulis.

Andronchev, I., Nikischenkov, S., Khaitbaev, V. (2020). Analysis and diagnostics of competing transport processes on the basis of the Bernstein-Russell-Narinyani theorem. In: Popovic, Z., Manakov, A., Breskicj, V. (eds.) VIII International Scientific Siberian Transport Forum Trans Siberia 2019, Advances in Intelligent Systems and Computing, 1115, 975-984. Springer, Cham.

Official website of the Mayor of Moscow. (2021). Department of Transport and Development of Road Transport Infrastructure of the City of Moscow: Model of freight frame in Moscow, https://www.mos.ru/dt/function/gruzovaia-logistika/gruzovoi-karkas/, last accessed 2021/03/15.

Yandex.Traffic.

Samara

service, https://yandex.ru/maps/51/samara/?l=trf\%2Ctrfe\&ll=50.172734\%2C53.205874\&z=11.23

Kurnikova, M., Bolgova, E., Dodorina, I., Haitbaev, A. (2019). Industry 4.0: Theoretical foundations and the strategic priorities of Russian regions. In: Veber, J., Guzikova, L. (eds.) New Silk Road: Business Cooperation and Prospective of Economic Development (NSRBCPED 2019), Advances in Economics, Business and Management Research, vol. 131, pp. 195-200. Atlantis Press, Paris.

SP 51.13330.2011 Noise protection. Updated version of SNiP 23-03-2003 (with Change N 1), http://docs.cntd.ru/document/1200084097, last accessed 2021/03/15. 